\title{
Apolipoprotein C3 (SstI) Gene Variability in Northwest India: A Global Perspective
}

\author{
Puneetpal Singh ${ }^{1}$, Monica Singh ${ }^{1}$, D.P. Bhatnagar ${ }^{1}$, Taranpal Kaur ${ }^{2}$ and Sarabjit Mastana ${ }^{3}$ \\ 1. Molecular Genetics Labortary, Department of Human Biology, Punjabi University, \\ Patiala, India \\ 2. City Medsave Hospital, Ferozepur, India \\ 3. Human Genetics Laboratory, Department of Human Sciences, Loughborough University, \\ Loughborough, UK
}

KEYWORDS Protein; ethnic groups; polymorphism; heart disease; medical genetics

\begin{abstract}
Apolipoprotein C3 plays an important role in the receptor mediated hydrolysis of triglyceride rich lipoproteins (TRLs) by inhibition of lipoprotein lipase (LPL), delayed clearance of which causes hypertriglyceridemia (HTG). Indians are considered to be more vulnerable to the adverse effects of hypertriglyceridemia and consequently its probable sequel of cardiovascular disorders. Several studies have revealed the association of rare allele (S2) of APOC3 (SstI) polymorphism with dyslipidemias and coronary artery diseases. In order to investigate the role and relevance of this polymorphism in Northwest India, the present study aimed to investigate the genetic variation of 3' untranslated region of APOC3 (SstI) in 312 individuals belonging to four endogamous groups (Banias, Brahmins, Jatsikhs and Khatris) of Punjab. Uncommon *S2 allele frequency was $22.6 \%, 22.5 \%, 22.7 \%$ and $26.2 \%$ in Banias, Brahmins, Jatsikhs and Khatris respectively. Higher heterozygosity of 0.39 in Khatris reflected their greater variation at this locus than the other populations. Chi-square analysis did not reveal any significant differences between these populations and other studies from North India $(P>0.05)$. Comparative analysis of 66 other populations across the world revealed large heterogeneity at this locus whereby, Mongoloid populations have the highest frequencies of $* \mathrm{~S} 2$ allele $(0.19$ to 0.48$)$ followed by Indians (0.18 to 0.29$)$, Africans (0.04 to 0.27$)$ and Caucasian populations (0.01 to 0.12 ). Genetic distance and multivariate analyses showed that Indian population is quite distinct from other Caucasian and Oriental populations. Clinal heterogeneity of predisposing *S2 allele in Asia showed an increasing cline $(\mathrm{y}=$ $0.0043 x+0.1209, R^{2}=0.1162$ ) towards North. As this allele is associated with HTG and other cardiovascular complications, differential variation in different populations may have insightful implications for association and medical genetic studies.
\end{abstract}

\section{INTRODUCTION}

APOC3 (protein: apoC-III; gene: APOC3) is a constituent of very low density lipoproteins (VLDL), chylomicron remnants and high density lipoprotein (HDL) particles (Mahley et al. 1984). It helps in the hepatic uptake of triglyceride (TG) rich lipoproteins (TRLs) and their remnants. Molecular perturbations of APOC 3 gene hampers the function of receptor mediated hydrolysis of circulating TRLs which augments the development of hypertriglyceridemia (Zeng et al. 1995), myocardial ischemia (Ginsberg et al. 1995) and carotid artery atherosclerosis (Sharrett et al. 1995).

The APOC 3 gene, flanked by APOA1 and APOA4 genes in a $15 \mathrm{~kb}$ cluster, is localized on

Address for Correspondence: Dr Sarabjit Mastana Human Genetics Lab., Department of Human Sciences Loughborough University, Loughborough LE11 3TU, UK.

Telephone: +44 1509 223041, Fax: +44 1509223940

Email: S.S.Mastana@LBORO.AC.UK

http://www.lboro.ac.uk/departments/hu/ 11q23.3 (Bruns et al. 1984). The cytosine (C, *S1 allele) to guanosine $(\mathrm{G}, * \mathrm{~S} 2$ allele) substitution in 3 '-untranslated region (3'UTR) of exon 4 in the APOC3 gene gives rise to an $S s t I$ restriction site (Karathanasis 1985) which has been studied extensively in relation to various lipid disorders. The frequency of *S2 allele varies greatly among populations of the world ranging from $0 \%$ in Europeans (Stocks et al. 1987) to 39\% in Japanese (Paul et al. 1987). The significant association of this allele with coronary heart disease (CHD) and diabetes (Rigoli et al. 1995) is partly attributed to the elevated triglycerides, plasma cholesterol, HDL and APOC3 levels (Rigoli et al. 1995; Ordovas et al. 1991) with some conflicting reports (Paul-Hayase et al. 1992; Tybjaerg-Hansen et al. 1993). As lipid levels are strongly related to cardiovascular disease risk (La Rosa et al.1990), it has been proposed that variation in the population frequency of $* S 2$ allele may genetically modulate lipids and lipoproteins differently in various populations and hence, conferring different disease risks. 
A large amount of data has been generated globally but, studies documenting the APOC3 gene variability in Indian population are scarce. Therefore, the present study was carried out to enlarge our knowledge about the functional consequences of APOC 3 polymorphism in four ethnic groups belonging to different social strata of Punjab, a Northwest state of India. In addition, we have carried out the global evaluation of these allele frequencies across 66 populations of the world and explored some plausible reasons of its wide differential disparity. These allelic dissimilarities may have insightful implications in disease association and medical genetic studies.

\section{MATERIALS AND METHODS}

Study Subjects: The present study comprised of total 312 (228 males, 84 females) unrelated and apparently normal individuals ranging in age from 20 to 65 years (mean age \pm SEM, $44.46 \pm 1.28$ ). The participants belonged to one of the four main ethnic groups, Banias $(n=73)$, Brahmins $(n=69)$, JatSikhs $(n=88)$ and Khatris $(n=82)$ from various places of Punjab representing social hierarchy and spoke both Punjabi and Hindi languages.

Ethnic Profiles of the Study Population: The people of Punjab are considered as the progeny of a mixture of many proto and post harappan invaders who entered this land from west and became original settlers of this area (Rose 1970). Banias in Punjab belong to Vaishya Varna of Indian caste system and mainly a mercantile community. Brahmins of Punjab are primarily Saraswat Brahmins and their vocation is teaching, performing priestly chores alongwith trade and industry. Khatri, a variant of the Sanskrit word Kashtrya were nomadic invaders who came and expanded into Central Asia and Europe, creating the similarities in Indo-European languages. The JatSikhs are the main agricultural community distributed all over Punjab. They are thought to be the progeny of Indo-Scythian / Indo-European / Indo-Aryan stocks. All these castes practise endogamy at the caste level and exogamy at gotra level. However, in the changing socio-economic circumstances, the rigidity in not having matrimonial alliances with the other castes is diluted.

APOC3 Genotyping: Blood was drawn from an antecubital vein into tubes containing disodium ethylenediamine tetra acetate (EDTA) to a final concentration of $1.5 \mathrm{mg} / \mathrm{ml}$. DNA was extracted from whole blood following standard phenol chloroform method. For Sst I polymorphic site, 596 bp fragment of APOC3/3'UTR was amplified using forward primer: 5'-CAT GGT TGC CTA CAG GAG TTC-3' and reverse primer: 5'TGT CGAAACACGCCT TCCAGT-3'. The PCR amplification was carried out in a final reaction volume of $25 \mu \mathrm{l}$ containing $\sim 100 \mathrm{ng}$ of genomic DNA, 0.4mM primers (Bangalore Genei, India), Genei PCR master mix (containing $0.2 \mathrm{mM}$ each of dATP, dCTP, dGTP, and dTTP, 1.25 units Taq DNA polymerase, $2.5 \mathrm{mM} \mathrm{MgCl} 2$ ). After the initial denaturation at $95^{\circ} \mathrm{C}$ for 5 minutes, $35 \mathrm{PCR}$ cycles were carried out as $95^{\circ} \mathrm{C}=1$ minute, $58^{\circ} \mathrm{C}=45$ seconds, $72^{\circ} \mathrm{C}=1$ minute with the final extension at $72^{\circ} \mathrm{C}$ for 7 minutes. The PCR products were digested with 10 units of SstI (New England Biolabs Inc., USA) in the presence of $1 \mu \mathrm{l}$ of $10 \mathrm{X}$ buffer provided with the restriction enzyme for 3 hours. The restricted products were electrophoresed on a $3 \%$ agarose gel prepared with TBE buffer and $0.5 \mathrm{mg} / \mathrm{ml}$ of ethidium bromide and visualized in a UV inspection unit. Internal validation of these polymorphisms was done by reanalysing some samples to avoid bias in genotyping error.

Statistical Analyses: Allele frequencies were estimated by gene counting method. The departure from Hardy-Weinberg equilibrium $\left(D_{A}\right)$ along with the statistical significance of RFLP was calculated according to the formulae

$$
D_{A}=P_{2 / 2}-p_{2}^{2} \text { and } \chi^{2}\left(D_{A}\right)=\mathrm{n} D_{A}^{2} / p_{1}^{2} p_{2}^{2}
$$

given by Haviland et al. (1991), where $P$ denotes genotype frequency; $p$ denotes relative allele frequency; 1 and 2 denote the frequent and rare allele respectively; $n$ is the number of subjects studied. Average heterozygosities were calculated by gene identities. Gene diversity analysis of $\mathrm{H}_{\mathrm{T}}, \mathrm{H}_{\mathrm{S}}$ and $\mathrm{G}_{\mathrm{ST}}$ statistics were calculated following Nei's (Nei et al. 1983) method. DA genetic distance (Nei et al. 1983) was calculated and the multidimensional distance matrix was reduced into UPGMA and Neighbor joining dendrograms. Correspondence analysis was carried out using NTSYSpc programme.

\section{RESULTS}

The distribution of APOC3 genotypes, estimated allele frequencies, heterozygosities $(\mathrm{H})$ and their departure from Hardy Weinberg equilibrium $\left(D_{A}\right)$ is summarized in table 1. Allele frequencies of $* \mathrm{~S} 1$ and $* \mathrm{~S} 2$ in all the studied 
Table 1: Genotype and allele frequencies of APOC3 (SstI) in four ethnic groups of North India.

\begin{tabular}{|c|c|c|c|c|c|c|c|c|c|c|c|}
\hline $\begin{array}{l}\text { Populations } \\
\text { (Numbers) }\end{array}$ & & S1S1 & & $S 1 S 2$ & & $S 2 S 2$ & $S 1 \pm S . E$ & $S 2 \pm S . E$ & $H$ & $D_{A}$ & $\chi^{2}$ \\
\hline Bani & 45 & 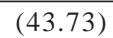 & 23 & $(2$ & 5 & ) & $0.774 \pm$ & 9 & & & 7 \\
\hline & 41 & & 2 & & 3 & & & & & & \\
\hline & 54 & $(52$ & 28 & $(30.5$ & 6 & & 0.7 & 5 & & & 78 \\
\hline & 47 & (44.64) & 27 & (31.73) & 8 & $(5$. & 0.738 & $0.262 \pm$ & 0 . & & 1.82 \\
\hline oled (312) & 187( & (182.31) & 103 & (112.37) & 22 & (17.31) & $0.764 \pm 0.024$ & $0.236 \pm 0.024$ & 0.36 & 0.015 & 2.17 \\
\hline
\end{tabular}

Values in parenthesis are expected numbers, H-Expected Heterozygosity, $D_{A}$ - Departure from Hardy Weinberg Equilibrium

populations showed trifle variations except Khatris where $* \mathrm{~S} 1$ and $* \mathrm{~S} 2$ showed slightly higher dissimilarity than Banias, Brahmins and JatSikhs. All the populations were in Hardy Weinberg equilibrium and did not show any significant variation $(P>0.05)$. Khatris showed higher heterozygosity $(39 \%)$ than other ethnic groups which reflected their higher heterogeneity and more gene flow than Banias, Brahmins and JatSikhs. However, the mean estimated heterozygosity $0.36 \pm 0.009$ in Northwest Indian populations (pooled) showed similitude with the Asian value ( $\approx 37 \%$ ). The overall pattern of allele frequency in the present study groups was found to be comparable with Asians but quite dissimilar to Caucasians.

The estimated allele frequencies and heterozygosities of APOC3 in various popu- lations across the world are given in table 2. An examination of this table clearly shows that the APOC3 polymorphism shows greater variation in Asian populations and demonstrates relatively lower polymorphism in Europeans. In Caucasians $*$ S2 allele was found to be the highest in Greeks (0.16) and lowest in Caucasians of UK (0.01) whereas, Mongoloids were found to exhibit the highest $* \mathrm{~S} 2$ allele frequency, $(0.48)$ in Chinese followed by Japanese (0.39) and Koreans (0.30). Average allele frequencies weighted upon sample size along with gene diversity analysis has been compiled in table 3 . Here, the Japanese $(0.36)$ but not the Chinese (0.298) showed highest weighted frequencies of $* \mathrm{~S} 2$ followed by Koreans (0.278), Indians (0.268) and least in Caucasians (0.079). Chinese $(44.3 \%)$, Japanese $(44 \%)$, Indians (36.7\%) and Asians (32.1\%) showed higher

Table 2: Allele frequencies and heterozygosities of APOC3 (SstI) polymorphism in various populations of the World.

\begin{tabular}{|c|c|c|c|c|c|c|}
\hline Study Populations & S1 & $S 2$ & $N$ & $H$ & Authors & Label \\
\hline \multicolumn{7}{|l|}{ Caucasians in Europe } \\
\hline Austrians & 0.890 & 0.110 & 118 & 0.196 & Paulweber et al. 1988 & $\mathrm{Au}$ \\
\hline Belgians & 0.890 & 0.110 & 162 & 0.196 & Paul-Hayase et al. 1992 & $\mathrm{Be}$ \\
\hline Danes & 0.910 & 0.090 & 261 & 0.164 & Tyajaerg-Hansen et al.1993 & $\mathrm{Da}$ \\
\hline Finland 1 & 0.920 & 0.080 & 61 & 0.147 & Aalto-Setala et al. 1987 & Fil \\
\hline Finland 2 & 0.860 & 0.140 & 50 & 0.241 & Miettinen et al. 1994 & Fi2 \\
\hline France (Lille) & 0.931 & 0.069 & 152 & 0.128 & Kee et al. 1999 & Frl \\
\hline France (Strasbourg) & 0.906 & 0.094 & 208 & 0.17 & Kee et al. 1999 & Frs \\
\hline France (Toulouse) & 0.912 & 0.088 & 215 & 0.161 & Kee et al. 1999 & Frt \\
\hline Greeks & 0.840 & 0.160 & 50 & 0.269 & Vavatsi et al. 1995 & Gr \\
\hline Italians 1 & 0.920 & 0.080 & 107 & 0.147 & Xu et al. 1990 & It 1 \\
\hline Italians 2 & 0.920 & 0.080 & 314 & 0.147 & Marasco et al. 1993 & It 2 \\
\hline Italians 3 & 0.919 & 0.081 & 62 & 0.149 & Rigoli et al. 1995 & It 3 \\
\hline Ireland (Belfast) & 0.944 & 0.056 & 186 & 0.106 & Kee et al. 1999 & Irb \\
\hline Norway & 0.880 & 0.120 & 33 & 0.211 & Kessling et al. 1986 & No \\
\hline Scotland & 0.880 & 0.120 & 117 & 0.211 & Morris and Price, 1985 & $\mathrm{Sc}$ \\
\hline UK (Bristol) & 0.920 & 0.080 & 90 & 0.147 & Kessling et al. 1988 & Uk2 \\
\hline UK (Caucasians) & 0.990 & 0.010 & 92 & 0.02 & Paul et al. 1987 & Uk3 \\
\hline UK (Caucasians) & 0.980 & 0.020 & 74 & 0.039 & Ferns and Galton 1986 & Uk4 \\
\hline UK (London) & 0.980 & 0.020 & 35 & 0.039 & Trembath et al. 1987 & Uk6 \\
\hline UK (London) & 0.980 & 0.020 & 47 & 0.039 & Ferns et al. 1985 & Uk7 \\
\hline UK (London) & 0.980 & 0.020 & 31 & 0.039 & Shoulders \& Baralle, 1986 & Uk 8 \\
\hline UK (London) & 0.960 & 0.040 & 81 & 0.077 & Vella et al. 1985 & Uk9 \\
\hline UK (London) & 0.940 & 0.060 & 73 & 0.113 & Kessling \& Humphries, 1985 & Uk 10 \\
\hline UK (London) & 0.930 & 0.070 & 123 & 0.13 & Ferns and Galton, 1986 & Uk11 \\
\hline
\end{tabular}


Table 2: Contd....

\begin{tabular}{|c|c|c|c|c|c|c|}
\hline Study Populations & $S 1$ & $S 2$ & $N$ & $H$ & Authors & Label \\
\hline Mediterraneans & 0.910 & 0.090 & 129 & 0.147 & Antonarakis et al. 1988 & $\mathrm{Me}$ \\
\hline \multicolumn{7}{|l|}{ Caucasians Elsewhere } \\
\hline Canada (Quebec) & 0.907 & 0.093 & 252 & 0.169 & Haviland et al. 1991 & $\mathrm{Ca} 1$ \\
\hline Canada (Vancouver) & 0.950 & 0.050 & 38 & 0.095 & Hayden et al. 1987 & $\mathrm{Ca} 2$ \\
\hline US (Boston) & 0.940 & 0.060 & 160 & 0.113 & Hegele et al 1989 & Us 1 \\
\hline US(Boston) & 0.920 & 0.080 & 145 & 0.147 & Ordovas et al. 1991 & Us2 \\
\hline US (Boston) & 0.896 & 0.104 & 371 & 0.186 & Liu et al. 2004 & Us3 \\
\hline US (Iowa) & 0.920 & 0.080 & 36 & 0.147 & Anderson et al. 1986 & Us4 \\
\hline US (Seattle) & 0.940 & 0.060 & 101 & 0.113 & Deeb et al. 1986 & Us5 \\
\hline US (Seattle) & 0.910 & 0.090 & 366 & 0.164 & Thompson et al. 1988 & Us6 \\
\hline US (Whites) & 0.905 & 0.095 & 823 & 0.172 & Hallman et al. 2006 & Us7 \\
\hline Australia-Anglo Irish & 0.940 & 0.060 & 47 & 0.113 & Buzza et al. 2001 & AAI \\
\hline Australia-Greeks 1 & 0.970 & 0.030 & 80 & 0.058 & Buzza et al. 2001 & AG1 \\
\hline Austrlalia-Italians 4 & 0.880 & 0.120 & 76 & 0.211 & Buzza et al. 2001 & AIt4 \\
\hline \multicolumn{7}{|l|}{ Chinese } \\
\hline Chinese 1 & 0.770 & 0.230 & 151 & 0.354 & Saha et al. 1995 & Ch1 \\
\hline Chinese 2 & 0.610 & 0.390 & 73 & 0.476 & Xiang et al. 1989 & $\mathrm{Ch} 2$ \\
\hline Chinese 3 & 0.520 & 0.480 & 20 & 0.499 & Rees et al. 1985 & Ch3 \\
\hline \multicolumn{7}{|l|}{ Japanese } \\
\hline Japanese 1 & 0.810 & 0.190 & 21 & 0.308 & Rees et al. 1985 & Jp1 \\
\hline Japanese 2 & 0.650 & 0.350 & 34 & 0.455 & Paul et al. 1987 & $\mathrm{Jp} 2$ \\
\hline Japanese 3 & 0.631 & 0.369 & 65 & 0.466 & Bai et al. 1995 & Jp3 \\
\hline Japanese 4 & 0.630 & 0.370 & 68 & 0.466 & Thompson et al. 1988 & $\mathrm{Jp} 4$ \\
\hline Japanese 5 & 0.620 & 0.380 & 74 & 0.471 & Aburatani et al. 1988 & Jp5 \\
\hline Japanese 6 & 0.610 & 0.390 & 35 & 0.476 & Rees et al. 1986 & Jp6 \\
\hline \multicolumn{7}{|l|}{ Koreans } \\
\hline Korea (Seoul) & 0.755 & 0.245 & 92 & 0.37 & Hong et al. 1997 & Ko 1 \\
\hline Korea (Seoul) & 0.699 & 0.301 & 131 & 0.421 & Song et al. 1998 & $\mathrm{Ko} 2$ \\
\hline \multicolumn{7}{|l|}{ Africans } \\
\hline Africa (Blacks) & 0.850 & 0.150 & 20 & 0.255 & Rees et al. 1985 & Af1 \\
\hline African- Americans & 0.832 & 0.168 & 360 & 0.28 & Hallman et al. 2006 & Af2 \\
\hline Blacks & 0.950 & 0.050 & 67 & 0.077 & Antonarakis et al. 1988 & Af3 \\
\hline South Africa & 0.940 & 0.060 & 42 & 0.113 & Henderson et al. 1987 & $\mathrm{Sa}$ \\
\hline UK (Blacks) & 0.870 & 0.130 & 53 & 0.226 & Thompson et al. 1988 & UkB \\
\hline UK (Negroes) & 0.730 & 0.270 & 28 & 0.394 & Paul et al. 1987 & UkN \\
\hline \multicolumn{7}{|l|}{ Asians } \\
\hline Arabs 1 & 0.980 & 0.020 & 31 & 0.039 & Tas 1989 & Ar 1 \\
\hline Arabs 2 & 0.840 & 0.160 & 63 & 0.269 & Johansen et al. 1991 & Ar2 \\
\hline Arabs 3 & 0.96 & 0.04 & 69 & 0.077 & Johansen et al. 1990 & Ar3 \\
\hline India (Punjabi Khatris) & 0.738 & 0.262 & 82 & 0.387 & Present study & Ipk \\
\hline India (Punjabi Banias) & 0.775 & 0.225 & 69 & 0.349 & Present Study & $\mathrm{Ipb}$ \\
\hline India (Punjabi Brahmins) & 0.774 & 0.226 & 73 & 0.35 & Present study & Iph \\
\hline India (Punjabi JatSikhs) & 0.773 & 0.227 & 88 & 0.351 & Present study & Ipj \\
\hline North West India 1 & 0.764 & 0.236 & 312 & 0.361 & Present study & Nwi1 \\
\hline Indian Asians & 0.820 & 0.180 & 28 & 0.295 & Rees et al. 1985 & Ia \\
\hline North India 2 & 0.704 & 0.296 & 216 & 0.417 & Chhabra et al. 2003 & $\mathrm{Ni} 2$ \\
\hline North India 3 & 0.688 & 0.312 & 151 & 0.425 & Chhabra et al. 2004 & $\mathrm{Ni3}$ \\
\hline UK (Indian Asians) & 0.81 & 0.19 & 24 & 0.308 & Paul et al. 1987 & UkI \\
\hline Philipinos & 0.770 & 0.230 & 84 & 0.354 & Johansen et al. 1990 & $\mathrm{Ph}$ \\
\hline Taiwanese & 0.736 & 0.264 & 159 & 0.389 & Huang et al. 2006 & $\mathrm{Ta}$ \\
\hline Vietnamese & 0.674 & 0.326 & 351 & 0.439 & Thu et al. 2006 & $\mathrm{~V}_{1}$ \\
\hline \multicolumn{7}{|l|}{ Other Ethnic Groups } \\
\hline Brazil & 0.890 & 0.110 & 100 & 0.196 & Relvas et al. 2005 & $\mathrm{Br}$ \\
\hline Dogrib Indians & 0.750 & 0.250 & 130 & 0.375 & Cole et al. 1989 & Di \\
\hline
\end{tabular}

average heterozygosities than Africans (22.4\%) and Caucasians $(13.7 \%)$ which manifest their greater differentiation at this locus (Table 3). It has been delineated that genetic diversity at APOC3 locus in Caucasians has the lowest total
$\left(\mathrm{H}_{\mathrm{T}}=0.141\right)$ and within subpopulation $\left(\mathrm{H}_{\mathrm{S}}=0.137\right)$ gene diversities whereas Chinese showed these indices to be the highest $\left(\mathrm{H}_{\mathrm{T}}=0.464, \mathrm{H}_{\mathrm{S}}=0.443\right)$. The percent of genetic differentiation $\left(\mathrm{G}_{\mathrm{ST}}\right)$ attributable between populations relative to total 
Table 3: Compiled data showing genetic diversity analysis of 70 populations across the world

\begin{tabular}{|c|c|c|c|c|c|c|c|}
\hline \multirow[t]{2}{*}{$\begin{array}{l}\text { Population } \\
\text { groups (number) }\end{array}$} & \multicolumn{2}{|c|}{$\begin{array}{l}\text { Average estimated } \\
\text { allele frequencies }\end{array}$} & \multicolumn{2}{|c|}{$\begin{array}{c}\text { Average frequencies } \\
\text { weighted upon sample size }\end{array}$} & \multicolumn{3}{|c|}{ Gene Diversity Analysis } \\
\hline & $* S 1$ & $* S 2$ & $* S 1$ & $* S 2$ & $G_{S T}$ & $H_{T}$ & $H_{S}$ \\
\hline Caucasians in Europe (25) & 0.924 & 0.076 & 0.921 & 0.079 & 0.026 & 0.141 & 0.137 \\
\hline Caucasians elsewhere (12) & 0.926 & 0.074 & 0.914 & 0.086 & 0.011 & 0.138 & 0.136 \\
\hline Chinese (3) & 0.633 & 0.367 & 0.702 & 0.298 & 0.046 & 0.464 & 0.443 \\
\hline Japanese ( 6) & 0.658 & 0.342 & 0.637 & 0.363 & 0.021 & 0.450 & 0.440 \\
\hline Koreans (2) & 0.727 & 0.273 & 0.722 & 0.278 & 0.004 & 0.397 & 0.396 \\
\hline Africans (6) & 0.855 & 0.145 & 0.851 & 0.149 & 0.094 & 0.247 & 0.224 \\
\hline Arabs (3) & 0.880 & 0.120 & 0.846 & 0.154 & 0.048 & 0.211 & 0.201 \\
\hline Asians (11) & 0.88 & 0.12 & 0.846 & 0.154 & 0.028 & 0.380 & 0.369 \\
\hline Indians (8) & 0.752 & 0.248 & 0.732 & 0.268 & 0.035 & 0.374 & 0.360 \\
\hline All populations (70) & 0.844 & 0.156 & 0.854 & 0.146 & 0.108 & 0.263 & 0.234 \\
\hline
\end{tabular}

genetic diversity was observed to be the highest in Africans (0.094) followed by Arabs (0.048), Chinese (0.046) and Indians (0.035). Considering all populations together only $10.8 \%$ of the total genetic diversity has been apportioned to between population variation.

The unbiased genetic distance (DA) was calculated for all 70 populations but the relationship was difficult to display and interpret. Therefore, allele frequencies for major groups were pooled and used for genetic distance calculations. In this analysis, all Caucasians (Europe and elsewhere) were pooled. The resultant multidimensional data matrix is reduced into UPGMA and Neighbor-joining dendrograms (Fig. 1A and 1B). Contrary to the expectations, Northwest Indian populations (pooled) form a distinct single point cluster separated widely from particularly the Caucasians and aligned as outer element to the cluster of East Asian populations.

Correspondence analysis of 70 populations is presented in figure 2 . In this plot, Caucasian

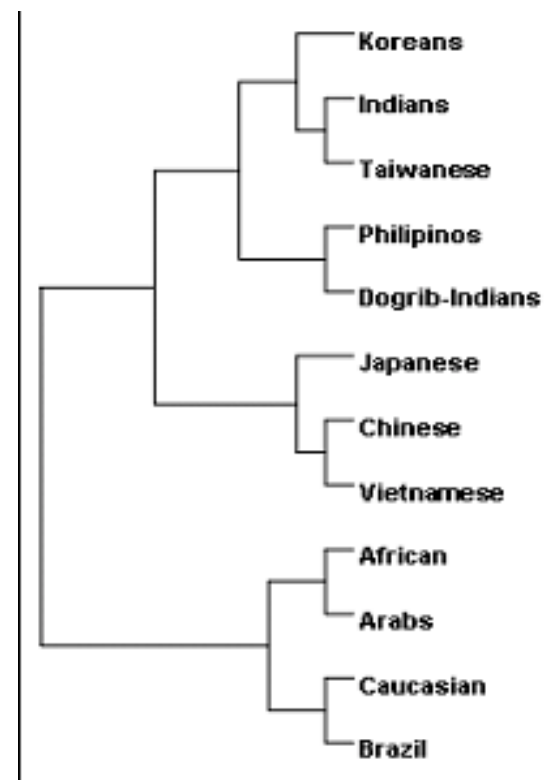

A) UPGMA dendrogram

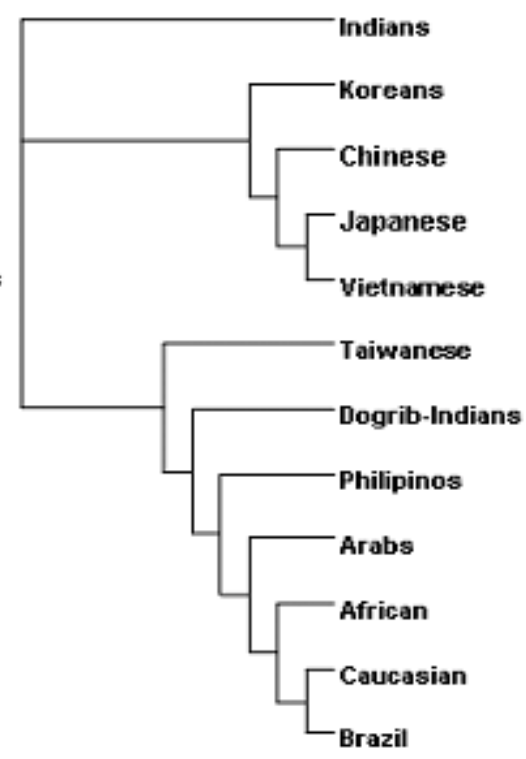

B) Neighbour joining dendrogram

Fig. 1. UPGMA and neighbour joining dendrograms of main populations based upon APOC3 SstI polymorphism 


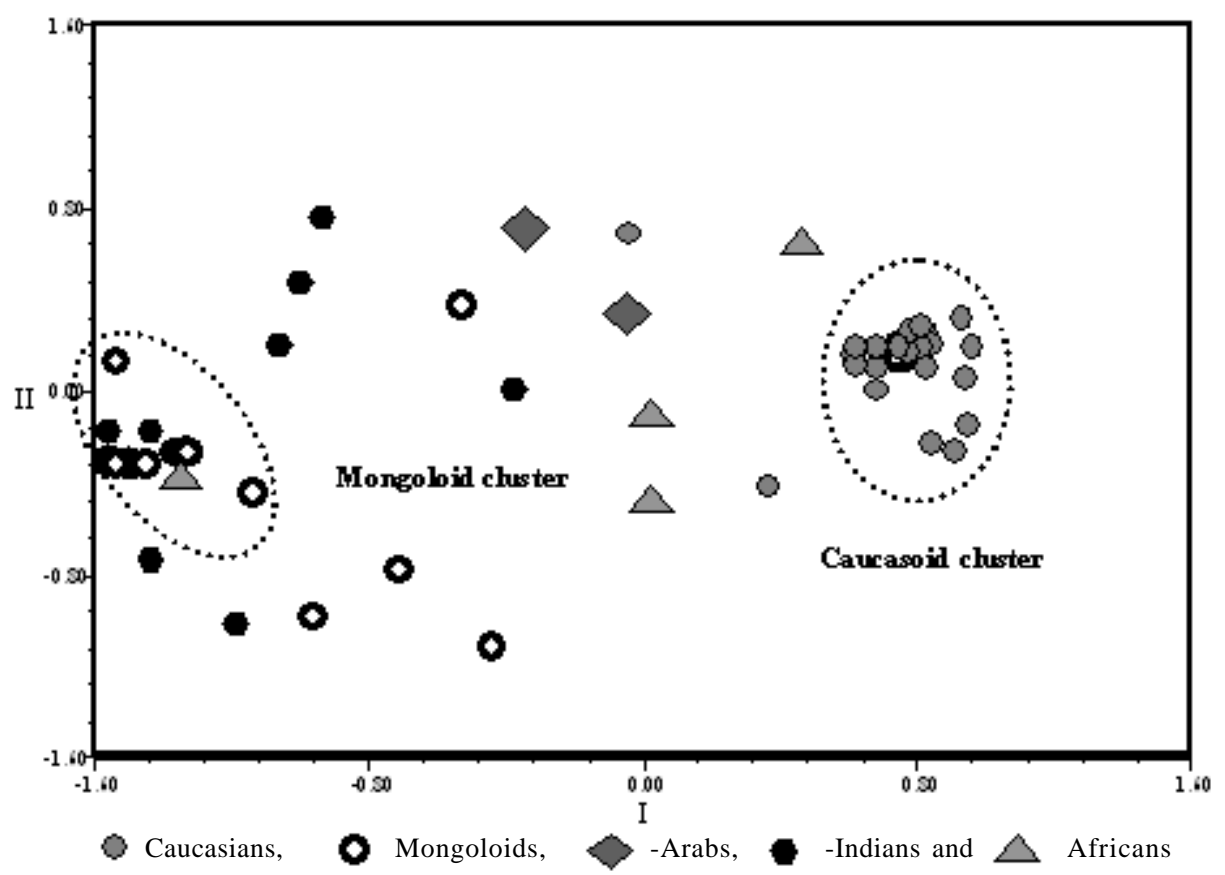

Fig. 2. Correspondence Analysis Plot of APOC3 allele frequencies

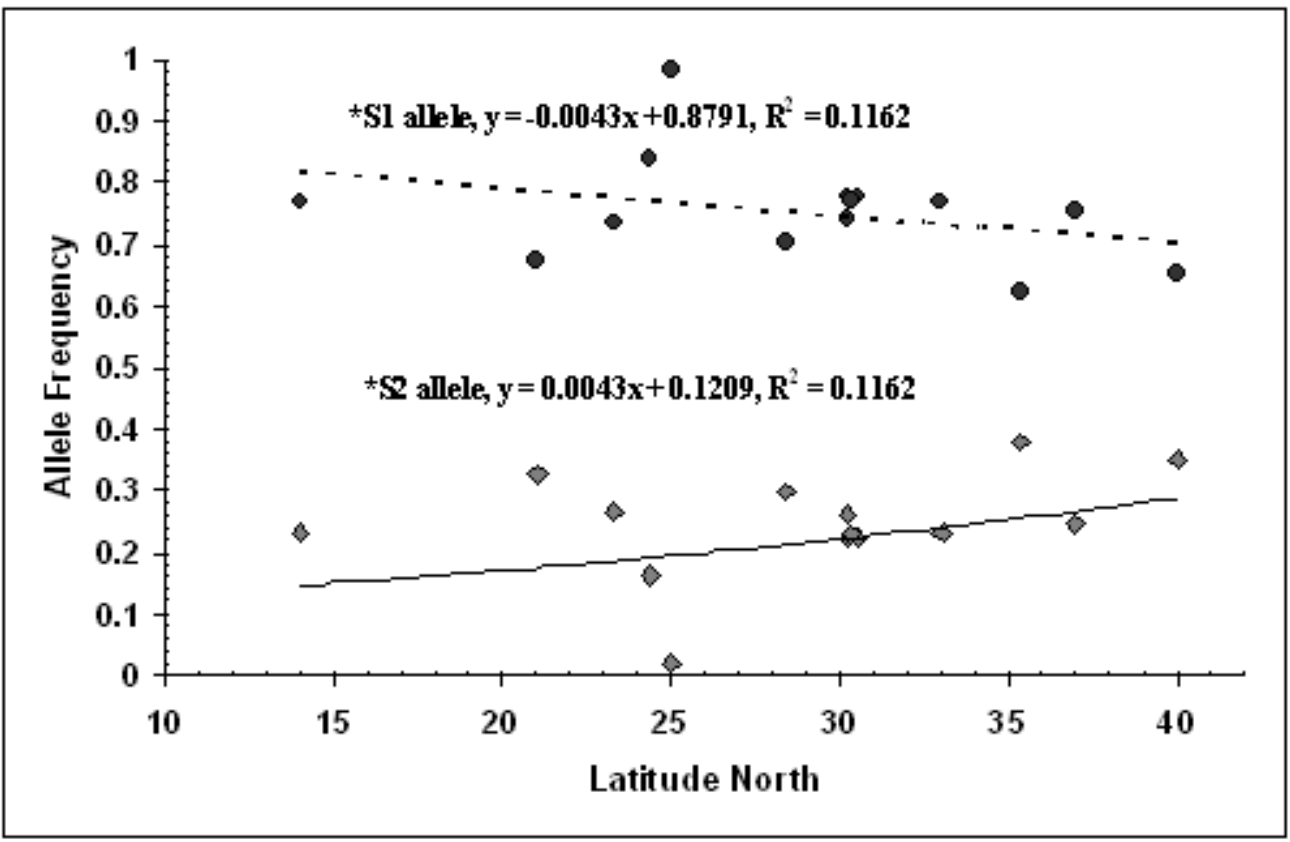

Fig. 3. Clinal heterogeneity of APOC3 in Asia 
populations from all over the world constitute a tight cluster on the right-hand side, while majority of Mongoloid along with Northwest Indian groups are on the left hand side. The African population groups along with Arabs are scattered in the middle. Three populations (Brahmins, Banias and JatSikhs) of Punjab form their own loose cluster on top left-hand side of the plot. Punjabi Khatri who showed slightly higher frequency of $* \mathrm{~S} 2$ allele is isolated from other Punjabi populations and is aligned towards Mongoloid populations (lower left hand side on the plot). The CA plot needs caution in interpretations as it is based only on single locus. Overall, the plot clearly shows that Indians form a distinctive group with reference to this locus.

Latitudinal correlated APOC3 polymorphism in Asia has been shown in figure 3 where decreasing cline of $* \mathrm{~S} 1$ allele $(\mathrm{y}=-0.0043 \mathrm{x}+$ $\left.0.8791, \mathrm{R}^{2}=0.1162\right)$ and increasing cline of $* \mathrm{~S} 2$ allele $\left(\mathrm{y}=0.0043 \mathrm{x}+0.1209, \mathrm{R}^{2}=0.1162\right)$ against the function of latitude North are evident which is found to be opposite in case of Europe (not shown).

\section{DISCUSSION}

The main aim of this study was to investigate the genetic heterogeneity of APOC3 SstI locus in four ethnically well defined populations i.e. Banias, Brahmins, Jat, Sikhs and Khatris of Punjab, a Northwest state of India which is considered to be the high incidence CHD belt. The alleles at APOC3 Sst locus display considerable variation between the present study and various other populations of the world confirming the wide range of incongruity at this locus both at regional and inter-regional level.

It is important to investigate different kinds of polymorphisms in different genes to understand spectrum and functional consequences of mutations. Therefore, it is recognized that investigation of APOC3, 3'UTR polymorphism is important as it has been associated with elevated serum triglycerides as well as increased risk of CHD in many populations and can be employed as an adjunct in CHD risk calculations, though not directly influencing or causing these disorders. Higher $* \mathrm{~S} 2$ allele frequencies in various ethnic groups of Punjab, a high fat consuming belt of India, may shed light on the adverse effects of $* \mathrm{~S} 2$ allele on these diseases. In the present sample, $40 \%$ of the individuals carried one or two copies of the susceptible allele and are therefore more susceptible for HTG and this may have public health consequences.

Regression analysis of APOC3 allele frequencies from 14 geographically well defined populations of Asia showed a contrast cline to that of European populations but none of the $\mathrm{R}^{2}$ values are statistically significant, so the interpretation needs prudence. Such clinal heterogeneity lenses the evolutionary factors like selection of the gene, which may be informative in dealing with overseas patients of different regions. Due to different linkage disequilibrium scores and their expression, selection may favour one genotype or allele at one extreme and disfavours it at other.

Continentally in Asia, when percent CHD mortality was compared with *S2 allele frequency, its association with CHD is consistent in China, India and Korea but not compatible with Taiwan, Japan and S. Arabia. In Europe also, there are instances where $* \mathrm{~S} 2$ allele is low in the areas where death certification (per 100,000) because of CHD is high like Ireland, UK and Denmark. The above comparisons need caution as direct correlations with a multifactorial disease like CHD are unlikely to be consistent in all populations. These imperfect associations of $* \mathrm{~S} 2$ allele expression with CHD in different populations of the world may have many unforeseen mechanisms involved. To begin with, it is possible that the influence of SstI RFLP on plasma TG could be potentially confounded by other neighboring loci such as APOA5, a newly identified TG regulator and modifier gene localised in the close proximity of ApoAI-CIIIAIV gene cluster. Secondly, it is also possible that SstI RFLP of APOC3 gene may be involved in modulating TGs differently in different ethnic groups because of its different linkage disequilibrium scores with other gene variants (coding or regulatory regions). Furthermore, as some haplotypes of APOC3 SstI and promoter variants affects TG homeostasis, therefore; this polymorphism may have some impact on $\mathrm{mRNA}$ stability as suggested by Smith et al. (1992).

Ordovas et al. (2002) has demonstrated that APO A-I gene of its Apo AI-CIII-AIV gene complex may influence response to environmental factors such as dietary fats. Differences in diet can be important link in the wide variability of APOC3 SstI polymorphism because dietary habits influence the same phenotypic CHD risk factor 
as minor allele $* \mathrm{~S} 2$ of this polymorphism (TG levels). From the last many years, it is well understood that it is better to monitor TG than cholesterol levels in determining hyperlipidemic status in countries like India, where generally low protein and high carbohydrate diet is consumed. In addition, Indians are considered to be more sensitive to the exacerbating effects of hypertriglyceridemia (Enas and Mehta 1995).

In the genetic landscape of APOC3 SstI polymorphism across various populations of the world, the nutritional behavior of some populations can be attributable to higher prevalence of *S2 allele despite having low CHD mortality for instance in Japan, China and S. Arabia. In these countries high protein and low carbohydrate/fat diet is consumed in comparison to India, Taiwan and Korea.

Perez-Martinez et al. (2001) has shown that *S2 allele may modulate the magnitude of atherogenesis and dyslipidemic state significantly $(P<$ 0.039) when patients changed their diet from saturated fatty acids (SFA) to Mediterranean diet (olive oil). Moreover, APOC3 polymorphism affects insulin response to oral glucose tolerance test (OGTT) in persons consuming high saturated fats (Salas et al. 1998). Thus, APOC3 SstI polymorphism plays an imperative role in determining the levels of lipid response to the dietary changes. Such inter-actions may be helpful to expose the link between inter population variability of CHD prevalence and APOC3 SstI polymorphism in relation to the dietary behavior.

\section{ACKNOWLEDGEMENTS}

We are indebted to all the study participants for their exceeding help and support. The support of the research grants by the Council of Scientific and Industrial Research to P.P.Singh and Department of Science and Technology, New Delhi to M. Singh is highly acknowledged.

\section{REFERENCES}

Aalto-Setala K, Kontula K, Sane T, Nieminen M, Nikkila E 1987. DNA polymorphisms of apolipoprotein A-I/C-III and insulin genes in familial hypertriglyceridemia and coronary heart disease. Atherosclerosis, 66: 145-152.

Aburatani H, Matsumoto A, Itoh H, Murase T, Takaku F, Itakura H 1988. Deoxyribonucleic acid (DNA) polymorphism in the apolipoprotein AI gene: A study in a Japanese population. Jpn J Med, 27: 5659.
Anderson RA, Benda TJ, Wallace RB, Eliason SL, Lee J, Burns TL 1986. Prevalence and associations of apolipoprotein A-I linked DNA polymorphisms: results from a population study. Genet Epidemiol, 3: 385-397.

Antonarakis SE, Oettgen P, Chakravarti A, Halloran SL, Hudson RR, Feisee L, Karathanasis SK 1988. DNA polymorphism haplotypes of the human apolipoprotein APOA1-APOC3-APOA4 gene cluster. Hum Genet, 80: 265-273.

Bai H, Saku K, Liu R, Imamura M, Arakawa K 1995. Association between coronary heart disease and the apolipoprotein AI-CIII-AIV complex in a Japanese population. Hum Genet, 95: 102-104.

Bruns GA, Karathanasis SK, Breslow JL 1984. Human apolipoprotein A-I-C-III gene complex is located on chromosome 11. Atherosclerosis, 4: 97-102.

Buzza M, Fripp Y, Mitchell RJ 2001. Apolipoprotein AI and CIII gene polymorphisms and their association with lipid levels in Italian, Greek and Anglo-Irish populations of Australia. Ann Hum Biol, 28: 481490.

Chhabra S, Narang R, Krishnan LR, Vasisht S, Agarwal DP, Srivastava LM, Manchanda SC, Das N 2003. Apolipoprotein C3 SstI polymorphism and triglyceride levels in Asian Indians. BMC Genet, 6: 3-9.

Chhabra S, Narang R, Lakshmy R, Vasisht S, Agarwal DP, Srivastava LM, Manchanda SC, Das N 2004. Apolipoprotein C3 SstI polymorphism in the risk assessment of CAD. Mol Cell Biochem, 259: 5966.

Cole SA, Szathmary EJ, Ferrell RE 1989. Gene and geneproduct variation in the apolipoprotein A-I/C-III/ A-IV cluster in the Dogrib Indians of the Northwest Territories. Am J Hum Genet, 44: 835-843.

Deeb S, Failor A, Brown BG, Brunzell JD, Albers JJ, Motulsky AG 1986. Molecular genetics of apolipoproteins and coronary heart disease. Cold Spring Harb Symp Quant Biol, 1: 403-409.

Enas EA, Mehta J 1995. Malignant coronary artery disease in young Asian Indians: thoughts on pathogenesis, prevention, and therapy. Coronary Artery Disease in Asian Indians (CADI) Study. Clin Cardiol, 18: 131-135.

Ferns GAA, Galton DJ 1986. Haplotypes of the human apoprotein AI-CIII-AIV gene cluster in coronary atherosclerosis. Hum Genet, 73: 245-249.

Ferns GAA, Stocks J, Ritchie C, Galton DJ 1985. Genetic polymorphism of Apolipoprotein CIII and insulin in survivors of myocardial infarction. Lancet, 2: 300-303.

Ginsberg HN, Jones J, Blaner WS, Thomas A, Karmally W, Fields L, Blood D, Begg MD 1995. Association of postprandial triglyceride and retinyl palmitate responses with newly diagnosed exercise-induced myocardial ischemia in middle-aged men and women. Arterioscler Thromb Vasc Biol, 15: 1829-1838.

Hallman DM, Srinivasan SR, Chen W, Boerwinkle E, Berenson GS 2006. Longitudinal analysis of haplotypes and polymorphisms of the APOA5 and APOC3 genes associated with variation in serum triglyceride levels: The Bogalusa Heart Study. Metabolism, 55:1574-1581.

Haviland MB, Kessling AM, Davignon J, Singh CF 1991. 
Estimation of Hardy-Weinberg and pairwise disequilibrium in the apolipoprotein AI-CIII-AIV gene cluster. Am J Hum Genet, 49: 350-365.

Hayden MR, Kirk H, Clark C, Frohlich J, Rabkin S, McLeod R, Hewitt J 1987. DNA polymorphisms in and around the Apo-A1-CIII genes and genetic hyperlipidemias. Am J Hum Genet, 40: 421-430.

Hegele RA, Hennekens CH, Breslow JL. 1989. Allele frequencies of apolipoprotein A-I and A-II gene locus DNA polymorphisms in Boston-based whites. Hum Hered, 39: 174-178.

Henderson HE, Landon SV, Michie J, Berger GM 1987. Association of a DNA polymorphism in the apolipoprotein C-III gene with diverse hyperlipidaemic phenotypes. Hum Genet, 75: 62-65.

Hong SH, Park WH, Lee CC, Song JH, Kim JQ 1997. Association between genetic variation of apoAICIII-AIV cluster gene and hypertryglyceridemic subjects. Clin Chem, 43: 13-17.

Huang MC, Wang TN, Liu YL, Pa TH, Tu HP, Huang YC, Chang WT, Ko YC 2006. Effect of SstI polymorphism of the apolipoprotein CIII gene and environmental factors on risks of hypertriglyceridemia in Taiwan aborigines. Circ J, 70: 1030-1036.

Johansen K, Dunn B, Tan JC, Kwaasi AA, Skotnicki A, Skotnicki M 1991. Coronary artery disease and apolipoprotein A-I/C-III gene polymorphism: A study of Saudi Arabians. Clin Genet, 39: 1-5.

Johansen K, Skotnicki A, Tan JC, Kwaasi AA, Skotnicki M 1990. Apolipoprotein A-I/C-III gene cluster polymorphism in Saudi Arabians, Filipinos and Caucasians. Clin Genet, 37: 194-197.

Karathanasis S K 1985. Apolipoprotein multigene family: tandem organization of human Apolipoprotein AI, CIII and AIV genes. Proc Natl Sci USA, 82: 63746378.

Kee F, Amouyel P, Fumeron F 1999 Lack of association between genetic variations of apo A-I-C-III-A-IV gene cluster and myocardial infarction in a sample of European male: ECTIM study. Atherosclerosis, 145: $187-195$.

Kessling AM, Berg K, Mockleby E, Humphries SE 1986. DNA polymorphisms around the apo AI gene in normal and hyperlipidaemic individuals selected for a twin study. Clin Genet, 29: 485-490.

Kessling AM, Humphries SE 1985. Interpretation of presence of S2 allele. Lancet, 2: 510-511.

Kessling AM, Nanjee MN, Miller NE, Humphries SE 1988. Variations in the apolipoprotein AI-CIII-AIV gene region and in lecithin:cholesterol acyltransferase concentration are determinants of plasma cholesterol concentrations. Atherosclerosis, 70: 1319.

LaRosa JC, Hunninghake D, Bush D, Criqui MH, Getz GS, Gotto AM Jr, Grundy SM, Rakita L, Robertson RM 1990. The cholesterol facts. A summary of the evidence relating dietary fats, serum cholesterol and coronary heart disease. A joint statement by the American Heart Association and the National Heart, Lung and Blood Institute. The task force on cholesterol issues, American Heart association. Circulation, 81: 1721-1723.

Liu S, Song Y, Hu FB, Niu T, Ma J, Gaziano M, Stampfer MJ 2004. A prospective study of the APOA1 XmnI and APOC3 SstI polymorphisms in the APOA1/
C3/A4 gene cluster and risk of incident myocardial infarction in men. Atherosclerosis, 177: 119-126.

Mahley RW, Innerarity TL, Rall SC Jr, Weisgraber KH 1984. Plasma lipoproteins: apolipoprotein structure and function. J Lipid Res, 25: 1277-1294.

Marasco O, Melina F, Mele E, Quaresima B 1993. Linkage disequilibrium of three polymorphic RFLP markers in the Apolipoprotein AI-CIII gene cluster on chromosome 11. Hum. Genet, 91: 169-174.

Miettinen HE, Korpela K, Hamalainen L, Kontula K 1994. Polymorphisms of the apolipoprotein and angiotensin converting enzyme genes in young North Karelian patients with coronary heart disease. Hum Genet, 94: 189-192.

Morris SW, Price WH 1985. DNA sequence polymorphisms in the apolipoprotein A-I/C-III gene cluster. Lancet, 2: 1127-1128.

Nei M, Tajima F, Tateno Y 1983. Accuracy of estimated phylogenetic trees from molecular data. II. Gene frequency data. J Mol Evol, 19: 153-170.

Ordovas JM, Civeira F, Genest J Jr, Craig S, Robbins AH, Meade T, Pocovi M, Frossard PM, Masharani U, Wilson PW, Salem DN, Ward RH, Schaefer EJ 1991. Restriction fragment length polymorphisms of the apolipoprotein A-I, C-III, A-IV gene locus. Relationships with lipids, apolipoproteins, and premature coronary artery disease. Atherosclerosis, 87: $75-86$.

Ordovas JM, Corella D, Cupples LA, Demissie S, Kelleher A, Coltell O, Wilson PW, Schaefer EJ, Tucker K 2002. Polyunsaturated fatty acids modulate the effects of the APOA1 G-A polymorphism on HDLcholesterol concentrations in a sex-specific manner: the Framingham Study. Am J Clin Nutr, 75: 38-46.

Paul H, Galton D and Stocks J. 1987. DNA polymorphic patterns and haplotype arrangement of the apoAI, ApoCIII and apoA-IV gene cluster in different ethnic groups. Human Genetics, 75: 264-268.

Paul-Hayase H, Rosseneu M, Robinson D, Van Bervliet JP, Deslypere JP, Humphries SE 1992. Polymorphisms in the apolipoprotein (apo) AI-CIII-AIV gene cluster: detection of genetic variation determining plasma apo AI, apo CIII and apo AIV concentrations. Hum Genet, 88: 439-446.

Paulweber B, Friedl W, Krempler F, Humphries SE, Sandhofer F 1988. Genetic variation in the apolipoprotein AI-CIII-AIV gene cluster and coronary heart disease. Atherosclerosis, 73: 125133.

Perez-Martinez P, Gomez P, Paz E, Marin C, Gavilan Moral E, Lopez-Miranda J, Ordovas JM, Fernandez de la Puebla RA, Perez-Jimenez F 2001.Interaction between smoking and the Sstl polymorphism of the apo C-III gene determines plasma lipid response to diet. Nutr Metab Cardiovasc Dis, 11: 237-243.

Rees A, Stocks J, Sharpe CR, Vella MA, Shoulders CC, Katz J, Jowett NI, Baralle FE, Galton DJ 1985. Deoxyribonucleic acid polymorphism in the apolipoprotein A-1-C-III gene cluster. Association with hypertriglyceridemia. J Clin Invest, 76: 10901105 .

Rees A, Stocks J, Paul H, Ohuchi Y, Galton D 1986. Haplotypes identified by DNA polymorphism at the apolipoprotein AI and CIII loci and hypertriglyceridemia. Hum Genet, 72: 168-171. 
Relvas WG, Izar MC, Helfenstein T, Fonseca MI, Colovati M, Oliveira A, Ihara SS, Han SW, Las Casas AA Jr, Fonseca FA 2005. Relationship between gene polymorphisms and prevalence of myocardial infarction among diabetic and non-diabetic subjects. Atheroscelrosis, 178: 101-105.

Rigoli L, Raimondo G, Di Benedetto A, Romano G, Porcellini A, Riccardi G, Squadrito G, Cucinotta D 1995. Apolipoprotein AI-CIII-AIV genetic polymorphisms and coronary heart disease in type 2 diabetes mellitus. Acta Diabetol, 4: 251-256.

Rose HA 1970. A glossary of the tribes and castes of Punjab and Northwest frontier province. Census Report, Language Department Punjab India, 1: 55-59.

Saha N, Tay J S, Low P S, Basair J, Hong S 1995. Five restriction fragment length polymorphism of ApoA1-C3 gene and their influence on lipid and apolipoproteins in healthy Chinese. Human Heredity, 45: 303-310.

Salas J, Jansen S, Lopez-Miranda J, Ordovas JM, Castro P, Marin C, Ostos MA, Bravo MD, JimenezPereperez J, Blanco A, Lopez-Segura F, PerezJimenez F 1998. The SstI polymorphism of the apolipoprotein C-III gene determines the insulin response to an oral-glucose-tolerance test after consumption of a diet rich in saturated fats. Am J Clin Nutr, 68: 396-401.

Sharrett AR, Chambless LE, Heiss G, Paton CC, Patsch W 1995. Association of postprandial triglyceride and retinyl palmitate responses with asymptomatic carotid artery atherosclerosis in middle-aged men and women. The Atherosclerosis Risk in Communities (ARIC) Study. Arterioscler Thromb Vasc Biol, 15: 2122-2129.

Shoulders CC, Baralle FE 1986. Genetic polymorphism in the ApoA-I/C-III complex. Methods Enzymol, 128: $727-745$.

Smith JD, Brinton EA, Breslow JL 1992. Polymorphism in the human apolipoprotein A-I gene promoter region. Association of the minor allele with decreased production rate in vivo and promoter activity in vitro. J Clin Invest, 89: 1796-1800.

Song J, Park JW, Park H, Kim JQ 1998. Linkage disequilibrium of Apo AI-CIII-AIV gene cluster and their relationship to plasma triglyceride, Apolipoprotein AI and CIII levels in Koreans. Mol Cells, 8: 12-18.

Stocks J, Paul H and Galton D 1987. Haplotypes identified by DNA restriction-fragment-length polymorphism in the AI-CIII-AIV gene region and hypertriglyceridemia. Am J Hum Genet, 41: 106118.

Tas S 1989. Strong association of a single nucleotide substitution in the 3 -untranslated region of the apolipoprotein-CIII gene with common hypertriglyceridemia in Arabs. Clin Chem, 35: 256-259.

Thompson EA, Deeb S, Walker D, Motulsky AG. 1988. The detection of linkage disequilibrium between closely linked markers: RFLPs at the AI-CIII apolipoprotein genes. Am J Hum Genet, 42: 113-124.

Thu NN, Mai TT, Ohmori R, Kuroki M, Chuyen NV, Hung NT, Kawakami M, Kondo K 2006. Plasma triglyceride and HDL-cholesterol concentrations in Vietnamese girls are affected by lipoprotein lipase, but not apolipoprotein CIII polymorphism. Circ J, 136: $1488-1492$.

Trembath RC, Thomas DJ, Hendra TJ, Yudkin JS, Galton DJ 1987. Deoxyribonucleic acid polymorphism of the apoprotein AI-CIII-AIV gene cluster and coronary heart disease in non-insulin-dependent diabetes. Br Med J, 294: 1577-1588.

Tybjaerg-Hansen A, Nordestgaard BG, Gerdes LU, Faergeman O, Humphries SE 1993. Genetic markers in the apo AI-CIII-AIV gene cluster for combined hyperlipidemia, hypertriglyceridemia, and predisposition to atherosclerosis. Atherosclerosis, 100: 157-169.

Vavatsi NA, Kouidou SA, Geleris PN 1995. Increased frequency of the rare PstI allele (P2) in a population of CAD patients in northern Greece. Clin Genet, 47: 22-26.

Vella M, Kessling A, Jowett N, Rees A, Stocks J, Wallis S, Galton D 1985. DNA polymorphisms flanking the apo A-1 and insulin genes and type III hyperlipidaemia. Hum Genet, 69: 275-276.

Xiang KS, Cox NJ, Sanz N, Huang P, Karam JH, Bell GI 1989. Insulin-receptor and apolipoprotein genes contribute to development of NIDDM in Chinese Americans. Diabetes, 38: 17-23.

Xu CF, Nanjee MN, Savill J, Talmud PJ, Angelico F, Del Ben M, Antonini R, Mazzarella B, Miller N, Humphries SE 1990. Variation at the apolipoprotein (apo) AI-CIII-AIV gene cluster and apo B gene loci is associated with lipoprotein and apolipoprotein levels in Italian children. Am J Hum Genet, 47: 429-439.

Zeng Q, Dammerman M, Takada Y, Matsunaga A, Breslow JL, Sasaki J 1995. An Apolipoprotein CIII marker associated with hypertriglyceridemia in Caucasians also confers increased risk in west Japanese populations. Human Heredity, 95: 371-375. 